\title{
DEATH AND THE HISTORY OF ISLAM IN HIGHLAND ACEH
}

\author{
John R. Bowen
}

\begin{abstract}
"The trouble is that we talk of ritual very much as if it were a thing in itself. . . In reality, the word merely describes chains of actions which .... are in a perpetual state of flux, so that, as we have seen, ritual may become the negation of ritual."
\end{abstract}

-A. M. Hocart, "Ritual and Emotion"

Perhaps everywhere, death carries with it certain moral, aesthetic, and sociological imperatives: the soul must be cared for, the body must be buried, the social order must be reaffirmed. 1 Robert Hertz, in his essay on death of 1907, linked these three imperatives together in a strikingly effective model of death as passage, both spiritual and corporeal. Hertz drew primarily from Indonesian materials; Arnold Van Gennep, in an essay published two years later, incorporated Hertz' insights into a general theory of rites of passage. 2 Hertz' conception of death has been particularly fruitful for students of Indonesia and other, related societies, as illustrated by its central theoretical position in two recent studies of mortuary ritual.

However, the form and meaning of mortuary rituals is not only a topic for anthropological analysis; it is also a subject for long-standing and hotly contested religious debates within Indonesia, between the proponents of Islamic modernism and those who would reaffirm the correctness of older, local ritual practices. My discussion will be of the susceptibility of death ritual to continuing reinterpretation by Indonesian Muslims, and the centrality of that

1. Earlier versions of this article were delivered at Cornell University on January 26, 1984, and Harvard University on March 20, 1984. I would like to thank those who attended the two seminars for their comments on the paper.

2. Robert Hertz, "A Contribution to the Study of the Collective Representation of Death," in Death and the Right Hand, trans. Rodney and Claudia Needham (Glencoe: The Free Press, 1960 [original in French, 1907]). Arnold Van Gennep, The Rites of Passage (Chicago: University of Chicago Press, 1960 [original in French, 1909]).

3. Maurice Bloch and Jonathan Parry, the editors of Death and the Regeneration of Life (Cambridge: Cambridge University Press, 1982), emphasize the recreation of society accomplished through mortuary ritual, while Richard Huntington and Peter Metcalf, in Celebrations of Death (Cambridge: Cambridge University Press, 1979), place more emphasis on the symbolics of the intermediary period and the reintegrating rituals. Both, however, make use of Hertz' analysis of mortuary ritual as a rite of passage. 
reinterpretive activity to religious dialogue in twentieth-century Indonesia. In particular, 1 am interested in the nature of the reformist-modernist interpretive dialogue as it has taken place in the Gayo highlands of Aceh. " I will suggest, first, that the "traditional" form of Gayo death ritual is the outcome of an appropriation of Islamic signs in a local cultural framework, and, second, that modernist reinterpretations of ritual have been carried out in a similar way, by highlighting some, and downplaying other, elements of the ritual.

But there is a further question, to which I will return at the end of the paper. Is the Hertzian model of death as the soul's passage neutral to these interpretive debates? Are we analytically engaged in the local debate without knowing it? I will suggest that, in our theory if not in our ethnography, we have emphasized precisely those aspects of mortuary ritual which are highlighted by Islamic modernism, and that we have done so for reasons of our shared intellectual heritage.

\section{Gayo Rituals of Death}

There are about 200,000 Gayo now living in the homeland Gayo area, the high plateaus of three kabupaten in central Aceh. The largest town, Takengon, has a population of about 10,000 , with another 30,000 Gayo in nearby villages. Those villagers who live near the town grow some wet rice and cash crops, primarily coffee and, very recently, the patchouli plant (Indonesian nilam) used for perfumes. Most Gayo, however, live in small villages of $300-1,000$ inhabitants located in the valleys of the mountainous highlands, and cultivate a mixture of wet rice and small amounts of tobacco and coffee.

While the process of Islamization began on the north coast of Aceh in the late thirteenth century, the conversion of the Gayo probably took place between the fifteenth and seventeenth centuries.' I have suggested elsewhere that Sufi ideas of being and creation which were expounded in coastal Aceh in the sixteenth and seventeenth centuries have been preserved as the basis for speculative theology and ritual practice in the Gayo highlands. 6 Gayo religious teachers themselves studied either in traditional religious schools on the north coast or from Naqsyabandiah tarekat teachers near Meulaboh on the west coast. I have found no indication of reformist influences in Gayo Islam prior to the coming of modernism in the 1920s. Initial Dutch contacts, and the beginning of first-hand written accounts, date from 1900, and the area was brought under colonial rule by 1905 . Over its long history in the region, Islam has played a major role in shaping Gayo political structure,

4. Fieldwork in the Gayo highlands was conducted between February 1978 and June 1980 with support from the Social Science Research Council, the National Science Foundation, and a Fulbright-Hays research grant, as well as administrative support from LIPI and sponsorship by the Universitas Syiah Kuala, Banda Aceh.

5. The only mention of the Gayo before the late nineteenth century is a short passage in the Hikayat Raja-Raja Pasai which states that the Gayo fled inland from the north coast in order to escape Islamization. I have examined the available early historical evidence in my Ph.D. dissertation, "The History and Structure of Gayo Society" (University of Chicago, 1984).

6. On this issue and the relation of the soul to the body, discussed below, see my "Islamic Transformations: From Sufi Poetry to Gayo Ritual," in Religion in Indonesia, ed. Rita Kipp and Susan Rodgers (forthcoming). 
ritual form, and local history, and to be Gayo, as to be Malay or Acehnese, is to be Muslim.

Most Gayo villages have remained traditionalist or kaum tue (old group) over and against the modernists or kaum mude (young group). Gayo death ritual in these villages is intelligible in terms of both pan-Indonesian culture and Near Eastern Islam. I find that this intelligibility is most easily understood as a local historical process of selecting ritual elements from an Islamic repertoire which are compatible with Gayo ritual practice. The Gayo theory of the transformation of the soul at death, similar to ideas found elsewhere in Indonesia, is, today, signified with Islamic ritual signs.

Gayo speak of four souls which together account for different psychic states during life and death. Briefly, the nyawa secures life, and its departure at death is sudden and irreversible. Gayo conceive of death as occurring in the instant when the Angel of Death wrests the nyawa out of the body. After death it ceases to play a role in the individual's social being. The semangat, on the other hand, is a kind of passive transformer of external actions (particularly those of malevolent spirits) into states of well- (or ill-) being. It, too, only exists during life. The ruh roams in and out of the body during life, allowing the individual to dream of distant places. Some Gayo say that this soul becomes the fourth category, the arwah, at (or even forty days before) death; others say that the two souls are separate entities which can move about independently. In any case, it is the arwah alone which plays a role after the moment of death.'

Death as it is experienced in traditionalist Gayo villages establishes a new relationship of the invisible, inner, batin soul to its visible, outer, lahir counterpart. Whereas before the moment of death the soul was primarily associated with a human body, after death it becomes gradually associated with a gravesite, where it may be called upon to aid the descendants of the deceased or the community as a whole. A series of mortuary rituals performed by the community serve to ease this process of transformation and to establish the new relationship between the living and the dead. Two key rituals in this series are the telkin, an instruction to the dead, and the kenduri, a series of ritual meals held at fixed intervals after death. Both are rites of communication with the soul of the deceased.

The Instruction to the Dead

All the souls leave the body at death, but the arwah hovers near the body as it is washed, wrapped in a white shroud, and carried to the place of burial. Burial takes place as soon as possible after death and is carried out by men

7. In Arabic, the word arwah is merely the plural of ruh. The notion that the two terms refer to separate classes of entities may have resulted from the use of the phrase "alam arwah," "world of the dead souls," or it may be part of the historical process of finding in Islam terms to correspond to pre-Islamic Gayo categories. In this case, the distinction between pre-mortem and post-mortem states of the soul has been mapped onto the grammatical distinction of singular and plural.

8. It is the gravesite and not the location of the buried body which marks the place of the post-mortem soul, since bodies of powerful individuals usually fly or walk away from their graves after death, leaving the soul behind, a point which I discussed in "Gayo Flying Graves," delivered to the Indonesian 
for both men and women. In the burial itself, as elsewhere in the Islamic world, the corpse is positioned on his or her right side and facing towards Mecca. A prayer is read aloud by the imem, and is joined in silently by all those present.

The primary concern after burial is to ease the "torment of the grave" (sikse kubur) experienced by the deceased's soul, to release it from early debts and spiritual sins, and deliver to it as much of the "pleasure of the grave" (nikmat kubur) as possible. The deceased is first reminded of the tenets of his religion. All those who witnessed the burial remain at the gravesite, while the imem takes hold of a stick inserted into the earth near the head of the grave and reads from a text called the telkin, from the Arabic talqin, "instruction." 10 As the imem reads the text, the arwah, which has remained near the head of body, listens, aided by the stick joining the imem to the grave. Near the beginning of the text is the passage "everything with a nyawa must die" which is read three times, slowly. Upon hearing these words, the arwah enters the body, allowing the person to awake from death and to feel the edge of his shroud, which, unlike all other clothes, has been left ragged. The deceased now realizes that he or she is dead.

The imem then continues, reading what one might call an Islamic catechism which reminds the deceased of the basic tenets of his religion: your God is Allah, your prophet is Muhammad, your book is the Qur'an, and so forth. This instruction is very useful to the deceased, as he will be visited momentarily by the two angels Mungkar and Nakir, who will pose these very questions to him, and beat him if he answers incorrectly. 11 The telkin is thus both a public demonstration of the continued sentient state of the dead person and a ritual of great instrumental importance in protecting him through his interrogations. As a sign of the possibility of communication with the deceased, the telkin acts as a ritual bridge to later exchanges and communications. As an instrumental ritual, it is seen by all those who are concerned about the deceased's welfare as a morally central part of the funeral.

Summer Studies Conference, Athens, Ohio, August 1983.

9. In a gender-based division of spiritual labor, the religious leadership of each village is invested in a single husband-wife pair, both referred to as the imem (although frequently reference to the wife is marked as imem banan, "female imem"). While the reading of prayer and performance of official public functions is the responsibility of the husband, the purifying and cooling of a bride and her mother, bathing of a newborn child, and the preparation of a female body for burial are responsibilities of the wife. Women never attend the burial.

10. The telkin is always in the form of an Arabic-language printed text, about three pages in length. Unlike all other important incantations or recitations it is never memorized, nor is it ever translated into Gayo as are most other lessons and instructions. It is thus as direct a conveying of the written word as is possible through speech, and serves as testimony to the power of written Arabic.

11. Similar talqin texts have been reported for elsewhere in the region. For a Malay text, see W. W. Skeat, Malay Magic (New York: Macmillan, 1900), pp. 406-7, and for Java, see Clifford Geertz, The Religion of Java (Glencoe: The Free Press, 1960), p. 71. Geertz reports that the text is sometimes read in Arabic and then in Javanese. 
The practice of giving a preparatory instruction to the dead person appears in other parts of the Islamic world. Eduard Westermarck, whose description of Moroccan Islam is still probably the most compendious, remarks that, in parts of Moroceo, Arabia, and Egypt, a slip of paper is put under the head of the deceased to remind him (or, I presume, although the matter is not clear, her) of the tenets of Islam, and that an oral instruction is frequently read after the burial as well. ${ }^{12}$ But the practice is performed in a solitary fashion, and appears to be not very important. Indeed, whereas much of Westermarck's ethnography consists of the naming of customs, he fails to provide a name for the post-mortem instruction. Its importance in Gayo culture thus appears to be due to local, rather than pan-Islamic cultural imperatives.

Feasting and Intervals

Ritual meals (kenduri) are held on the first, third, seventh, and forty-fourth nights after the death. ${ }^{13}$ These meals are put on by the immediate family of the deceased and of ten involve substantial expense. All men and women in the village of the deceased are invited to attend, and most women help in cooking, and men in chanting.

The primary materials of the kenduri consist of foods, of which the deceased will be sent the essence (berkat), and prayers, chanted by the assembled guests, of which the deceased will receive the merit (pahala). Always present at funeral meals are the small, round cakes called apam, made from rice flour, which have the inner property of holding off the clubs of the interrogating angels during the days of torment. The apam are also used for making requests to God. Two kinds of rice are served at the meals. While regular rice (kro) provides nourishment for the living, glutinous rice (kunyit) has the property of providing sustenance for the dead; in both cases sustenance comes from the spiritual property, or essence (berkat, from Arabic baraka, "blessing") of the food. Finally, benzoin incense (kemenyen) serves to carry words and berkat to God, Who is asked to pass them on to the soul of the deceased.

Words said at the kenduri generate merit and transmit it, through God, to the deceased. Texts are chosen which praise God and mention His name, thereby pleasing $\mathrm{Him}$, and leading Him to reduce the suffering and excuse the sins of the dead. Thus, the Qur'anic verses, Al-Ikhlas, which contains the name of God, and Al-Fatihah, which contains the essence of the entire Qur'an (i.e., God's words), are very frequently recited at the meals. The form of the recitations is either as "Qur'anic reading" (ngaji), in which each man present takes a turn at reading a verse, or as shamadiyah (from Arabic shamad, "eternal"), in which all those present chant verses in unison, repeating the same verse over and over again. In both cases the recitation is under the leadership of a tengku (religiously learned person), through whom the merit of the verses is channeled to God. I was told that the merit is only sent if the correct intent (niet) is held by the tengku at the meal.

If someone who is not a diligent Muslim, who never prayed, dies, a tengku will still come and pray and chant, but these prayers

12. Eduard A. Westermarck, Ritual and Belief in Morocco, 2 vols. (New Hyde Park, N.Y.: University Books, 1968 [original 1926]), 2: 464-65.

13. The word kenduri refers to any kind of formal meal, including those held for weddings, agricultural rituals, and healing. In fact, the word may be used as a refined way of referring to an ordinary meal. 
will be external only (lahir), so that the family will not be embarrassed. The prayers will not "hit the mark" because the tengku will think to himself: "He never prayed; how can we ask for his redemption." The result is seriet berules, hakiket beropoh [behavior in a ceremonial cloth; inner reality in a plain cloth]; just going through the motions.

In the case of the shamadiyah, the verses generate merit as the simple product of the number of repetitions and the number of chanters. In the sessions at which I was present, the chants were repeated twenty to thirty times; a repetition of 1,000 by a tengku (regardless of the number of others present) is said to redeem the sins of the deceased completely. In any case, all verses are said to be redemptions (penebus) for sins, and also to be the alms of the living (sedekah, from the Arabic shadaqah, "alms") given to the deceased by his "pious-performing children" (anak amal saleh).

The four funeral kenduri also demarcate stages in the transformation of the relationship of soul to body. I draw the following descriptions from funerals witnessed in Isak in 1979 and 1980. The first meal follows soon af ter burial.

Preparations for the meal begin immediately after the body is made ready for burial. Large cooking pots are set up outside the house of the deceased, and women from throughout the village bring foodstuffs and help in the cooking. Most of the adult men of the village join in the ngaji session, and everyone takes a turn at reading a verse, and thus sending merit to the deceased, no matter how unsuited his voice may be to the task. Recitation continues until after midnight. Over the next three days, all cooking is done collectively in the large pots. No special prohibitions mark the behavior of close relatives during this period, and crying over the deceased is usually met with a remonstrance to the effect that to bewail the departed is to deny God His due.

During the three days after death the body is said to be intact, and the soul remains within it.

The ritual held on the third night is called the nenggari. The meal is less well attended, with perhaps a third as many men ngaji as on the first night. During the period following this meal, the body begins to decompose and the spirit moves restlessly in and out of it. The first seven days are days of torment for the soul, and the close relatives say an extra prayer at each of the five prayer times for its well-being. The widow, widower, or children of the deceased burn incense and put out apam cakes each day for the seven days, also with the purpose of reducing the torment. Rice and vegetables are put out each night for the soul, which is said to be both in and out of the house and near the body.

The seventh-day meal, nujuh, is the largest and most important of the series, and distant relatives will make a particular effort to attend. Many different kinds of cakes are made by women in the village for the meal, and everyone turns out. A shamadiyah chanting session is held, lasting about one hour. The climax of the ritual series comes on the following day, how ever (still part of the seventh day by Gayo time reckoning), when men and women visit the grave, and a daytime meal is held at which the closest relatives ask forgiveness. It is on the seventh day that arwah leaves the decomposed body. The grave, not the body, is now the home of the soul. The funeral 
of my closest informant's mother occurred when I was in the village, and on the seventh day:

\begin{abstract}
About a dozen of the closest relatives, both men and women, went to the grave, which had not been touched since burial, the men carrying stones, water, and uncooked rice, and the women carrying mungkur fruit [a ritually important citrus] and white cloth. Two men took two large, smooth stones and, putting a white cloth underneath each, placed them at the head and foot of the grave at the same moment, pronouncing the tasbeh [the expression of praise to God beginning "Subhana'llah"] as they did so. Then the women began to lay the smaller stones on the grave, saying the tasbeh to themselves as they did so. Then water was sprinkled on the grave, and everyone said the Al-Ikhlas (eleven times each, I was told later on) to himself before leaving. The tasbeh and the Al-Ikhlas are both in praise of God, and bring merit to the deceased. The stones will continue to say the tasbeh forever, on the deceased's behalf.
\end{abstract}

After visiting the grave, the family hold a kenduri at their house, with apam cakes and rice. The occasion is one of emotional climax, a release from the too-correct tension and stoic conduct of the first seven days.

The main topic of conversation were the debts left by the mother. They must be settled quickly or she will feel torment [sengsara] in her grave. The son grew angry because there were debts which he had not known of, and the time needed to repay them would thus be longer. The Prophet said we should pay off all debts before the dead is buried, I was told, but during the seven days we may need to borrow more for the meals, so we only repay after the nujuh.

But when he was finished, the son quickly leaned over to his father and crouched low to place his head in his father's hands [semah] and beg forgiveness for his mistakes. Then he did the same with everyone else, and so did the others who stood as children to the father. Everyone but the eldest son was crying, and one daughter started a long ritual cry. This moment was the first moment of release from the sadness and frustration of the previous week. Whereas crying at the moment of death was frowned on as defying God's will, crying now was over the event itself, the sadness they were all feeling. Even the suave imem from downstream [a "son" of the deceased] was crying.

This set of events on the seventh day constitutes the critical point of transformation. The soul is released from the body, the deceased is released from his worldly debts, and the live actors in the sequence released from their pent-up emotions. The period between death and the seventh day corresponds to what Hertz called the "intermediary period," which is represented in some Indonesian societies by the exposed corpse. Hertz' insight was that, in such societies, the exposed, decomposing body was the material basis for the theory of the soul's passage; Gayo also know of decomposition as a natural process, and similarly key ritual to it without exposing the corpse. 14

14. Hertz, "Contribution to the Study," pp. 29-53. 
During the period between the seventh and the forty-fourth day, the soul wanders in and out of its former house, remaining in or near the village. The debts which were figured out on the seventh day must be paid off during this period for the future peace of the soul. A small meal is held on the forty-fourth night, called the nyawah lo, "ending the days," at which apam cakes and glutinous rice are given to the arwah, and it leaves the house.

The spirit may return to the community at such times as it is called, or at certain fixed, propitious moments (e.g., the night before Friday prayers, or during the fasting month). But after the forty-fourth day the arwah is said to have left for the awang-awang, a place that lies somewhere between heaven and earth. The awang-awang is not a well-defined place, and the phrase is tantamount to saying, in our figurative sense, "up in the clouds." But, at the same time, the arwah is also spatially associated with the gravesite. Graves are visited frequently, cleaned, and sprinkled with water to "cool" the soul. A soul whose grave has been neglected may cause sharp, painful twinges in its descendants' stomachs as reminders that the grave needs to be visited.

All ancestors have healing powers, and any grave might be visited with a request to help cure an illness by interceding with God, since a deceased soul is closer to God than is a living person. The graves of prominent persons, particularly ancestors of important descent lines (kuru) are particular efficacious sources of healing power, and are visited by a wider range of people. The agricultural season is marked by kenduri at a third category of ancestors graves, those of the founders of the community (datu) who are called on for permission to plant the land, for assistance in ridding the fields of pests, or who are given thanks for a good harvest.

The force of mortuary ritual is thus dual: it both eases the dead soul out of the community and locates it at a gravesite in the community. This "inherent bilocality of the dead," as Peter Metcalf has termed it, is in fact a transformation of the relationship between soul and body, from one of containment to one of mediation. 15 The power of the soul after death stems precisely from its role in overcoming the opposition between the community and the distant world of spiritual power. Power is drawn down to aid the community in its worldly needs.

This ritual pattern of easing out, and then communicating with, the soul appears to be present in non-Islamic societies in the Malayo-Indonesian world as well. For several Borneo peoples, for example, an initial period when the village is in danger and prohibitions are applied to a close relative of the deceased (often lasting seven days), is followed by a passage of the soul out of the community. However, the dead, from their graves in the land of the living, also continue to provide health and well-being to the community. 16

15. Peter Metcalf, A Borneo Journey into Death. Berawan Eschatology from Its Rituals (Philadelphia: University of Pennsylvania Press, 1982), p. 235.

16. See ibid., pp. 109-10, 225-29, for the Berawan cosmology of the dead and the songs describing their journey. Alfred B. Hudson, "Death Ceremonies of the Ma'anyan Dayaks," Sarawak Museum Journal 13 (1966): 341-417, describes similar Ma'anyan rites. In Ngaju, seven days after the burial is the moment when a flame which has been lit at burial is snuffed out "so that it will accompany the deceased to the world of the spirits." See Sarwoto Kertodipoero, Kaharingan: Religi dan Penghidupan (Bandung: Sumur Bandung, 1963), pp. 60-63. 
While we know nothing of the nature of Gayo death ritual before Islamization, Islam did make available certain signs which could have taken on local meanings, and thus religiously sanction pre-existing practices. The periods of three, seven, and forty or forty-four days after death appear in the Near Eastern Islamic world as common limits on mourning, taboos, and the moments for special meals. In parts of Morocco, cooking is prohibited for the first three days after death and a widow may not venture outside during that period. The first meal cooked at her home, and her first visit to the grave take place on the seventh day, and seven days is also the period of women's wailing in several parts of the Near East. Forty-four days frequently is the moment for a special meal on the grave of the deceased. 27

The kenduri would have provided a new form in which communication with the dead could be carried out. Syafi'i law books which are used by Indonesian scholars equate the Persian term kenduri with the Arabic shadaqah, "alms," but as alms given by the host to his guests, rather than to the soul of the deceased.1. I suggest that the kenduri and the talqin have become key funeral rituals for the Gayo because they were appropriate vehicles for Gayo ideas of the transformation of the soul at death, as both passage and continued speech, i.e., a form of passage which preserves ties of communication and transmission, or, thought of spatially, the "inherent bilocality" of the dead soul. Modernism, as we shall see below, has reinterpreted these signs in such a way as to downplay communication and emphasize passage, linearizing, in effect, the soul's progress.

\section{Islamic Modernism and Religious Ritual}

The history of Islam in Sumatra might be characterized as a series of reformisms, each one reinterpreting previous texts, institutions, and practices in a new light. Earlier reformisms include the or thodox reaction to Sufi ideas of being in seventeenth century Aceh, the rise of legalistic Islamic interpretations in eighteenth-century West Sumatra, and the socially purifying emphasis of the Padri movement in the same area. 19 In this century, modernist reformism in Sumatra and elsewhere in Indonesia has been dominated by the influence of the Kaum Muda (Young Group) movement, which received major contributions from the Sumatra Thawalib schools movement in West Sumatra, the Muhammadiyah, which began in Java but quickly spread to Sumatra and elsewhere, and the Persatuan Islam group led by Ahmad Hassan in Bandung. All three centers have influenced Gayo modernism.

Indonesian modernism was a combination of progressive Arabic thought in the Near East and a long-standing tradition of Indonesian (and particularly Sumatran) revivalism. Cairo was the center for a rethinking of the relationship

17. See Westermarck, Ritual and Belief, pp. 438-510, for descriptions of the funeral periods mentioned here.

18. Howard M. Federspiel, Persatuan Islam: Islamic Reform in Twentieth Century Indonesia (Ithaca: Cornell Modern Indonesia Project, 1970), p. 71.

19. See Christine Dobbin, Islamic Revivalism in a Changing Peasant Economy: Central Sumatra, 1784-1847 (London and Malmo: Curzon Press, 1983), on the eighteenth century and the Padri movement, and Shekh Muhammad Naguid al-Attas, The Mysticism of Hamzah Fansuri (Kuala Lumpur: Oxford University Press, 1970), on the seventeenth-century religious debates in Aceh. 
of the Islamic faith to the Western social and scientific world of the late nineteenth century. Jamaluddin al-Afghani and his student, Mohammed Abduh, wrote of the need to reinterpret Islamic rules and adapt them to a modern world. 20

The most important direct link between the Cairo modernists and Indonesian scholars was, ironically, the Shaf $i^{\prime} i$ imam at the Masjid al-Haram in Mecca. 21 Born in West Sumatra, Syekh Ahmad Chatib, a Minangkabau, came to Mecea to study, and became, not only the Shafi'i leader, but also the most important teacher of those Indonesians who were studying in Mecea in the $1890 \mathrm{~s}$. His influence is illustrative of the potential for reform within traditionalist frameworks. Although he upheld the teachings of the Shafi'i school against the direct reinterpretation of Scripture, he did not forbid his students from studying the writing of Mohammed Abduh and other modernists. Moreover, because he based his opinions strictly on an Islamic foundation, he was an outspoken opponent of Minangkabau matrilineal inheritance law and the joint lineage control of property, and of the several mystic orders (tarekat) that were prominent in Minangkabau society in this period. 22

Students of Ahmad Chatib combined their teacher's criticisms of traditional society with the modernist teachings of Mohammed Abduh, and on their return to Indonesia in the early years of the twentieth century began to found modernist schools and movements in Indonesia. Kyai Haji Ahmad Dahlan, after his studies in Mecca in the $1890 \mathrm{~s}$, returned to Java where he founded, in 1912, the Muhammadiyah movement, while in 1919 others among Ahmad Chatib's students established the Sumatra Thawalib schools movement in Padang Panjang, West Sumatra.23

\section{The Modernist View of Ritual}

I now turn to the content of the dialogue that ensued between the Kaum Muda and the various groups and positions collectively referred to as the Kaum Tua, the "old group," which included traditional orthodox teachers (among them the Nahdlatul Ulama), but not the Javanese abangan syneretists, and only indirectly the spiritualist tarekat groups. This dialogue has continued to

20. On the influence of Abduh and al-Afghani, see Albert Hourani, Arabic Thought in the Liberal Age, 1798-1939 (Oxford: Oxford University Press, 1962), pp. 103-60. The texts of the debate between al-Afghani and Ernest Renan on the relationship of Islam and science were secretly carried into Indonesia, and, to this day, a current of Islam-as-science thinking remains extremely popular in Takengon, including much speculation about the computerization of the Qurtan and the "prediction" of the atomic bomb in Scriptures.

21. Each of the four traditional schools was represented at the mosque by a leader or imam. The four schools were criticized by the modernists as perpetuating error; see below.

22. Deliar Noer, The Modernist Muslim Movement in Indonesia, 1900-1942 (Kuala Lumpur: Oxford University Press, 1973), pp. 31-33.

23. On the growth of Muhammadiyah, see ibid., pp. 73-83, and Mitsuo Nakamura, The Crescent Arises over the Banyan Tree: A Study of the Muhammadiyah Movement in a Central Javanese Town (Yogyakarta: University of Gadjah Mada Press, 1984). On the Sumatra Thawalib, see Taufik Abdullah, Schools and Politics: The Kaum Muda Movement in West Sumatra (1927-1933) (Ithaca: Cornell Modern Indonesia Project, 1971). 
constitute the primary field of discourse concerning Islam in Indonesia up to the present day. 24

At the national level, this debate took place between (on the modernist side) novelists, journalists, and theologians who criticized, point by point, what they saw as un-Islamic practices, and (on the traditionalist side) long treatises summing up as many scriptural justifications for each such practice as could be found. The debates have largely avoided confrontations over broad social issues, but have remained focused on questions of strictly religious practice. Two specific lacunae in these debates are worth mentioning. First, traditionalists have not made reference to specific Indonesian cultural characteristics in defense of their interpretations of Islam, perhaps because of the cultural heterogeneity of Indonesia. Second, modernists have not, in these religious debates, made the question of allegiance to a non-Islamic state a central issue, probably because of the early alliances between modernists and the nationalist movement.

The position of the Young Group may be explained through their use of the two terms ijtihad (individual interpretation) and bid'a (innovation). The first is promoted and the second attacked. The fundamental truths, say the Kaum Muda, were set out in the Qur'an and hadith (traditions concerning the words and deeds of the Prophet), and in every age these two sources must be applied directly to current conditions through ijtihad, i.e., by examining Scriptures to determine the legal prescriptions or moral teachings contained therein, and then using reason to apply them to a contemporary situation. An attitude of unquestioning obedience (taqlid) to any one set of established interpretations is criticized, both because it stands in the way of modernity and progress, and because the interpretations of the four schools, one of which, the Shaf $i \mathrm{i}$, is followed in Indonesia, may lead to heteropraxis.

These errors in the main turn on the second key concept, bid' $a$, or innovation. For the modernists, any change in a matter of worship (ibadah) is not permitted, since God himself ordained such matters and man cannot improve on them. Unless a practice can be justified by reference to clearly acceptable scriptures (and it is on the relative acceptability of various hadith that the argument of ten stands) it ought not to be followed.

On the other hand, continues the argument, one must strictly delimit matters of fixed ritual, the true domain of ibadah, from aspects of worship or religion in which the purpose is highlighted over the form. Thus, sermons and homilies which are delivered publicly, or individual prayers which are said silently, ought to be in the vernacular, rather than in Arabic, since these acts are primarily acts of communication and do not have a fixed ritual form. Similarly, some modernists consider the washing performed before the ritual prayer as primarily a cleansing act (highlighting purpose) rather than as a ritual act (highlighting form), and thus argue that it may be replaced by a good shower.

24. Among the texts used by Gayo in Takengon to support their positions on the following matters are, on the modernist side, Ahmad Hassan dkk. [et al.], Soal-Jawab tentang berbagai masalah agama (Bandung: Diponegoro, 1968), and the same author's Pengajaran Shalat (Bandung: Diponegoro, 1979 [original 1930]). The leading writer of Islamic texts in Aceh is T. M. Hasbi Ash-Shiddieqy, who takes a modernist position on the issues discussed here. See his Al-Islam, 2 vols. (Jakarta: Bulan Bintang, 1952), 2: 247-48. Prominent among Shafi'i traditionalist scholars is the 40 Masalah Agama of K. H. Sirajuddin Abbas, 4 vols. (Jakarta: Pustaka Tarbiyah, 1976). 
For the same reason, continue the modernists, the washing may not be performed in shorthand fashion, by wetting three hairs of the head, as is of ten done by traditionalists. 23

While modernists emphasize strict delimitation, and the proscription of any worship-related practice not clearly prescribed by Scriptures, the traditionalists emphasize the power and goodness of many ritual practices, some of which are only recommended rather than required. Traditionalists base their arguments on the writings of famed older scholars and frequently mentioned practices or sayings of the Prophet. They thus accept a greater number of actions as having been sanctioned, in practice, by the Prophet. These actions range from the ritually incidental (the Prophet stood up when a funeral bier passed, so we should as well), to the instrumental (the Prophet was said to read a talqin to keep a dead man from torment, so we should as well), to the socially desirable (the Prophet spoke Arabic, and so, ideally, should we). 26

Modernists refuse to use those traditions for which the chain of communication (sanad or isnad, lit. "support") is not composed of unimpeachable sources, primarily a matter of the moral character of those who transmitted the tradition. Modernists also frequently reason from analogy and employ arguments of the form "if we were to accept this, then...."

Proper conduct of funerals has been a salient issue in the debates between modernists and traditionalists throughout Indonesia, although in some areas it has been eclipsed by other social issues (e.g., inheritance law in West Sumatra). I will suggest that the prominence of mortuary ritual in the debates is due to the adoption of Islamic signs to support what is seen by modernists as a pre-Islamic system of communication.

Nationally, the most vocal debates on the issue of the talgin were carried out in the 1930s between Ahmad Hassan, the strictest constructionist of modernism, and various exponents of the Shafi'i position. Hassan's view, and that of the modernists generally, was based both on a strict examination of the isnad of those traditions claimed as supporting the practice (each was found to be weak), quotations from the Qurian, and what was offered as simple good sense: how could the dead possibly hear the instruction? Among those verses cited in opposition to the instruction to the dead was An-Naml (The Ant) 27:80, which reads: "You cannot make the dead hear, nor make the deaf hear the call when they have turned to flee." Thus, conclude the modernists, the practice is useless, as the Qur'an itself states, and "is the work of fools." What is worse, since it is not a prescribed part of the funeral ritual, and since the funeral is part of ibadah, the instruction to the dead is an illegitimate innovation (bid'a) and thus must not be carried out. 2 ?

The modernist objections to post-mortem kenduri were on similar grounds. All traditions which claimed that the Prophet had attended such meals were stated to be weak. Special objections were made to those meals (such as the Gayo kenduri of the third and seventh days after death) which have as their

25. See Ahmad Hassan, Pengajaran Shalat, p. 202.

26. I know of several Gayo families who moved to the Pekalongan area of Java, one with a large number of people of Arab descent, and adopted Arabic as their language of the home.

27. Ahmad Hassan, Soal-Jawab, 1: 210-14, and Pengajaran Shalat, pp. 365-67. See also Ash-Shiddieqy, Al-Islam, 2: 247-48. 
purpose the generation of merit on behalf of the deceased. If it were possible to transmit merit to someone else by our actions, objected the modernists, then why would we ever need to worship? Surely it would be easier to ask someone else to pray for us. But clearly we do have a duty to worship, so merit must not be transferable. $2:$

The response of the traditionalist text writers on these issues was to amass traditions and authorities speaking for the practice. Such writers as Sirajuddin Abbas (one of the most widely read) insisted on the correctness of using hadith that have weak histories if they concern matters of optional worship and not the central pillars of Islam. 29

\section{Gayo Modernists and the Nature of Death}

Modernist ideology came to Takengon in the late 1920s, when Minangkabau traders brought an attractive combination of trading skills, modern forms of education, and what seemed to some to be a more rational form of Islam. These reformers-cum-peddlers quickly sought protection from Raja Bukit, the native ruler (Zelfbestuurder) in Takengon, in order to avoid being branded as Communists by the Dutch, 30 The traders, members of Muhammadiyah, built a mosque in the center of town at which services were conducted in the modernist manner. 31 Many Gayo traders became adherents of Muhammadiyah, and several Gayo left for schooling in modernist schools in West Sumatra and Java in the 1930s, and returned several years later to build the indigenous modernist movement.

Three social features of the movement determined its overall character in Takengon. First, modernism grew out of cross-ethnic social relations, led by newcomers to the region. It brought the expansion of trade outside the Gayo region, new forms of education, and an emphasis on the Indonesian language. The focus of the movement was on problems of religion in general, rather than on the particular institutions of Gayo society (as was not the case in West Sumatra, where reformists were of local origin, and had been taught by Syekh Chatib to oppose matrilineal institutions). Second, the movement enjoyed strong support from a powerful traditional ruler. This support provided an additional factor diverting Gayo modernism from the kind of direct attack on traditional social and political structures that was carried out in Minangkabau and Acehnese societies. Third, modernism has benefited from the powerful political position of the ulama (religious leaders) in postindependence Aceh as a whole. ${ }^{32}$ Modernism thus established itself as a supraethnic, town-based movement with strong local and regional political support.

28. Ahmad Hassan, Soal-Jawab, 1: 216-19, and Federspiel, Persatuan Islam, pp. 70-74.

29. Abbas's defense of the talqin is in Abbas, 40 Masalah, 4: 78-126.

30. By that time, the Sumatra Thawalib school in West Sumatra had developed an "ilmu kominih" (Communist branch of knowledge) (Abdullah, Schools and Politics, p. 41.

31. The mosque is still commonly referred to as the mersah Padang (after the capital of West Sumatra).

32. A series of violent confrontations between the ulama and the traditional rulers in coastal Pidie shortly after Independence firmly established the 
The institutional base of modernism in Takengon was in the Muhammadiyah schools. In 1934 a five-year Muhammadiyah school was erected in Takengon and taught a broad range of subjects, including some Dutch language instruction. The Raja Bukit signaled his support for the movement by laying the corner stone for the school, which was the first alternative in Takengon to the three-year Dutch volksschool. In 1938 a second modernist-minded five-year school was opened, the Pendidikan Islam (Islamic Education), which taught mathematics and geography as well as religious subjects.

Until independence in 1945 the only traditionalist alternatives in Takengon to these two schools were the pondok schools of Qur'an recitation; children from traditionalist families thus had to seek further study in coastal Aceh. In 1957, how ever, a branch of the Medan-based al-Washliyah movement was opened in Takengon. This was a moderate traditionalist movement designed to support traditional shaf i'i religious views without rejecting the possibility of alternative positions. From 1970 to 1975 this group operated a university in Takengon, which produced nineteen nationally recognized BA graduates and had a total enrollment of 300 students. Arabic language learning and religious subjects were emphasized.

Gayo modernism has remained centered on the town of Takengon, but it began to make its influence felt in a number of villages in the $1930 \mathrm{~s}$, when divisions occurred over the issue of proper Frday prayer procedure, and groups of Kaum Muda adherents moved out to set up their own reformed communities. A number of villages near Takengon remain divided between modernists and traditionalists, with each keeping to its own mosque and prayer house (mersah). More isolated villages are virtually all traditionalist. Perhaps 85-90 percent of Gayo remain traditionalist by their own admission.

The emphasis of Gayo modernist reformism has been on three areas of Gayo culture: technical issues regarding the forms of ritual worship (shalat), the status of bridewealth and inheritance, and the propriety of mortuary rites. While the first two issues, shalat and property transfers, have given rise to extended debate within the Gayo community, they are both seen as technical matters, where each individual ought to choose to follow either a traditional set of practices or a modernist one, without a socially necessary uniformity of religious practice.

In both the administration of the shari'a (Islamic law) and communal worship, a high degree of contextual segregation between kaum mude and kaum tue is possible. In the Islamic court (Mahkamah Shari'a), Islamic law must take precedence over local precedent if an inheritance question comes to a formal decision, but the judges of the Takengon Court prefer that families reach informal settlements among themselves rather than be made subject to the imposition of shari'a. Traditional inheritance rules involve a division of property among those children who remain in the lineage after marriage, but there is not the salience of a non-Islamic inheritance rule such as characterizes Minangkabau society; the issue is thus relatively low-key within the culture as a whole. Similarly, rather than quarreling over forms of the shalat, modernists and traditionalists tend to build separate mosques in the community and to carry out their respective services in their own ways.

former as the political elite of Aceh. See Anthony Reid, The Blood of the People: Revolution and the End of Traditional Rule in Northern Sumatra (Kuala Lumpur: Oxford University Press, 1979), pp. 185-217. 
The Religious Centrality of the Funeral

It is the third issue, the proper conduct regarding the dead, that has become the primary, salient, and unavoidable religious diacritic in Gayo society, the issue around which Gayo must publicly sort themselves into kaum tue (or Shaf ${ }^{\prime}{ }^{\prime}$ ) and kaum mude (or Muhammadiyah).

While national-level debates on the legitimacy of funeral rituals have centered on the acceptability of particular hadith, the discourse within Gayo society has focused on the possibilities of communication between the living and the dead. Modernists reinterpret death ritual by highlighting one aspect of the soul's transformation, namely, its passage out from the body of the deceased and the community of the survivors. While the traditionalist's means of guaranteeing health and prosperity are predicated on communicating with the dead, it is precisely this possibility of communication that is radically undercut by modernists, who see it as illegitimate innovation in what is essentially a religious matter.

For the modernists in Takengon and the villages near the town, the moment of death itself breaks the ties between the deceased and the community at large. Once the nyawa has left the body, the person can no longer hear instructions read to him, and his fate in the grave can no longer be altered nor his merit increased, by the performance of feasts or by providing apam cakes. "For the dead," say the modernists, "good deeds ('amala) no longer help you, except for three: children who do good works (anak amal saleh), alms given while alive (sedekah jariah), and useful knowledge taught to others (ilmu manf a'at)."

This text is a hadith from Abu Daud, and quoted by modernists and traditionalists alike, but from opposed interpretive perspectives. : 3 For the traditionalist, the tie of the deceased to his anak amal saleh is interpreted to imply the duty of his "children" in the widest sense to organize large and effective ritual meals and chanting sessions, in order to generate merit for the deceased. For the modernist, however, the passage is read as strictly limiting those who are capable of improving the lot of the deceased to his "real" children, and even then only in their prayers to God. 34 To do otherwise, to engage in telkin or kenduri, is to carry out an illegitimate innovation (bid'a) or addition to what may properly be done at a funeral. Moreover, appeals to the deceased for assistance in life are viewed as setting up alternatives to God (nduei Tuhen, "duplicating God"), and thus constitute the sin of polytheism (syirk [Gayo musrik]).

Instead of the telkin, modernists remind the person near death of the tenets of his religion, and urge him to die with the words la ilaha ilallah (there is no God but Allah) on his lips. The "torment of the grave" is equally important to modernist notions, but it is a torment the outcome of which is entirely dependent on the preparation of the deceased for death during his life, and there is nothing we can do to intervene directly, except offer our prayers to God to treat his soul with compassion. The soul is already beyond the reach of the community. Modernist Gayo funerals involve a burial, with a short prayer but no telkin, and a short gathering at the home of the deceased

33. It is cited in Ahmad Hassan, Soal-Jawab, 1: 218.

34. An ethnobiological view of kinship runs throughout much modernist discourse, some of it based on a tendency within Islamic law to favor real over adoptive children in matters of inheritance. 
without a meal. Sometimes guests might bring food for the family of the deceased, but they would not partake of it themselves.

The textual methods of modernism thus involve emhasizing a definitive transition from sentience to nonsentience as the essence of death. In this view, the crucial break between the body and soul occurs on the first day after death, rather than with the release of the arwah from the body on the seventh day. Death, for the modernist, is primarily passage from this world to the next. After death, the living have very little to do with the dead.

The modernist view thus denies the living their accustomed avenues of recourse in the case of illness or poor crops, or merely when they wish to ensure prosperity. The gravesites, which for the living serve as markers of Gayo history, are deprived of their power as executors of fortune over the land and its inhabitants. Moreover, the deceased is no longer to be treated as one of the community. As one friend of mine put it: "You cannot treat a person like a chicken, just throw him away when he dies."

Villagers see the issue as a general conflict over the possibility of communication between living persons and other beings. A traditionalist village leader gave me the following answer when I asked him about the differences between modernists and traditionalists:

Another difference [he said, after talking about prayer] is with the shamadiyah. There, we have a meal and we chant to reach the dead person. The Kaum Muda says that the chant could not reach him because he is already dead. But that is like saying that when we go by a grave and say "How are you doing in there, in the grave?" that he cannot hear us. But of course he can, only we cannot hear his answer--he does answer, though.

It is like the Prophet Suleiman: in his time, people could talk with the plants and the animals, and the dead could answer our questions. But since then it has been forbidden. But trees, for instance, have souls--you know because they have green leaves that they must. We were taught by our teacher that if you must cut down a tree you have to say "bismillah irahman irahim" first, to the tree. That was Teungku Bit, a Sufi teacher.

Disagreement over religious ritual form is thus perceived as implicating the general relationship between the living and all other elements in the world, including dead souls, plants, and spirits. The debate is thus one on which, at least for the traditionalists, the prosperity of the community rests.

While in the majority of Gayo villages the population is entirely kaum tue, and thus traditional ritual form and function is preserved, in the villages near Takengon and in the town itself the population is mixed. Here, the issue of proper funeral form serves as an unavoidable test of one's stand on the traditionalist/modernist issue generally. The salience of funerals is due to three characteristics of the ritual: the mortuary rituals are public, involving performance of chants and prayers and attendance at ritual meals; socially obligatory for all kin, neighbors and nearby acquaintances of the deceased; and religious, in that their content clearly has to do with God, spirits, and human communication with both. Modernists are unable to explain away mortuary rituals as "culture" (kebudayaan) or "tradition" (adat), and therefore they are forced to take a religious stand on the propriety of the rituals. Modernists cannot refuse to stay away from traditionalists' funerals, because 
doing so would violate rules of social etiquette. Moreover, one's mere attendance at a funeral ritual signals a level of acceptance of the entire proceedings. The result is to place modernists in a double bind, where one cannot attend (for religious reasons) and also cannot not attend (for equally compelling, or nearly so, social ones). It is the unavoidable signaling of religious commitment that takes place in attending a funeral that has made these rituals central arenas in the modernist/traditionalist debate.

When I attended funeral meals, I frequently saw uncomfortable modernists for whom even the taking of a glass of water represented a religious deviation, but for whom the cultural prescriptions of feast attendance still weighed heavily. The only funeral during the period of my fieldwork at which successful spatial segregation of modernists and traditionalists occurred $w a s$ at the death of the brother of the Bupati of Central Aceh. Because the Bupati's house is a uniquely large and multiroomed structure, it is subject to different symbolic valuations than is an ordinary house: rather than a basic front room for male guests and a back room for close friends and female guests, the Bupati's state house has several, well-separated front rooms, an arrangement which allowed him to escape choosing between religious feast styles by holding two ceremonies at once after his brother's death. At one ceremony were the traditionalist villagers, largely on his father's side, who ate splendidly on that and the succeeding nights; at the other were the modernist town folk, largely on his mother's side, who were not even served tea, but prayed briefly and left.

\section{Models and Modernism}

Modernism had acted, I have argued, by reinterpreting texts and ritual forms already in place, highlighting the elements of passage contained in Gayo funerals and denying the elements of communication which are also contained therein. Modernism has thus proceeded in a fashion analogous to a model of early Islamization proposed here, by adopting certain Islamic texts as guides to the evaluation of earlier cultural forms, and transforming them in a way that remains recognizable to members of the society.

The advent of modernism in Gayo society, and, mutatis mutandis, elsewhere in Sumatra, has brought about the confrontation of two radically different ideas of ritual. One is the "life-giving" ritual of the village traditionalists, which is concerned with the well-being of the dead and the health, fertility, and prosperity of the living community. Mortuary ritual underscores the continuity of communication between the living and the dead and the possibility of mutual assistance; from the living to the dead during the mortuary ritual series, and vice-versa thereafter. This sort of ritual is Hocart's "ritual of life" based on a conception of "life, fertility, prosperity, vitality." 35

The opposing idea of death ritual sees it as primarily or even uniquely, a passage out of this world into another, emphasizing the rupture between the living and the dead at the moment of death, and the eventual judgment

35. A. M. Hocart, Kings and Councillors (Chicago: University of Chicago Press, 1970 [original 1936]), pp. 32-33. James Boon suggested the fruitfulness of Hocart to this analysis. On Balinese parallels to the contrast I draw below, see James Boon, Other Tribes, Other Scribes (Cambridge: Cambridge University Press, 1982), pp. 200-204. 
of the dead at the end of the world. Reintegration, in this conception, must await Judgment.

In this conflict of local interpretations, our use of the Hertz-Van Gennep model of death as a rite of passage favors the second, linear, modernist idea, rendering elements of communication secondary to the main lines of the ritual as a whole. Hertz himself pointed to the fact that, in some Indonesian societies, the soul continues to carry on "regular relations" with the living after death. This observation, however, was a minor addendum to his general model in which a return to the living occurs only after a journey to a distant, separate, world of the dead, a final resting place for the soul. The world of the dead serves to provide a "realm of the ideal" for the living. "6

For Hertz, the Olo Ngaju presage another, more elaborated model of passage and eventual return which is to be found in Christianity. The idea of "the resurrection and the life" guaranteed by the Church appears at the end of Hertz' analysis as a "rejuvenated form" of secondary burial, a passage et retour which completes earlier forms of the religious life (and death). 37

Modernist Islam, in its return to Scriptures for its revisions of local practice, shares a Judaeo-Christian-Islamic eschatology with Hertz, so that parallels between Hertz' analytic emphasis on passage and the similar interventions of the modernists are not fortuitous. In both, the radical separation of the dead from the living converts death from a transformation of the soul which underwrites Life into a prelude to an eventual moral Judgment. An emphasis on sequence in itself, one could argue, casts continuity in a background role, and makes communication and protection dubious characteristics of the dead. If not the negation of ritual, a single model of the general form of mortuary ritual may be an analytic party to its radical revision.

36. See Hertz, "Contribution to the Study," pp. 61, $59 \mathrm{ff} ., 79$, respectively, for the passages cited above.

37. Ibid., pp. 77-79. 